\title{
Metal Cluster-Based Electrochemical Biosensing System for Detecting Epithelial-to-Mesenchymal Transition
}

Ying Han ${ }^{1}$, Cuicui Qiu ${ }^{2}$, Jiaojiao Li $^{1}$, Fuping Gao ${ }^{3}$, Qing Yuan ${ }^{1}$, Yuhua Tang ${ }^{1}$, Wenchao Niu ${ }^{1}$, Xiayan Wang ${ }^{1}$, Xueyun Gao ${ }^{1}$ and Liang Gao *1

${ }^{1}$ Department of Chemistry and Biology, Faculty of Environment and Life Science, Beijing University of Technology, Beijing 100124, China

${ }^{2}$ State Key Laboratory of Tribology, Tsinghua University, Beijing 100084, China

${ }^{3}$ CAS Key Laboratory for Biomedical Effects of Nanomaterials and Nanosafety, Institute of High Energy Physics, Chinese Academy of Sciences, Beijing 100049, China

*To whom correspondence should be addressed. E-mail: gaoliang@bjut.edu.cn. 


\section{Supplementary Experimental Methods, Results and Discussion}

\section{Text S1. ICP-MS Analysis of the AuCs Concentration}

The concentration of purified gold clusters was determined by an ICP-MS analysis system. In detail, $10 \mu \mathrm{L}$ of purified clusters samples were digested overnight with $4 \mathrm{~mL}$ of aqua regia. Then, the mixed solution was evaporated to $0.1 \sim 0.2 \mathrm{~mL}$ and diluted by 5000 times with $2 \% \mathrm{HNO}_{3}$ and $1 \%$ $\mathrm{HCl}$ to appropriate concentrations. Bismuth solution with a concentration of $20 \mathrm{ppb}$ was used as the internal standard solution. The standard curve was obtained by measuring different concentrations of gold standard solutions $\left(0.5,1.0,5.0,10,50,100 \mathrm{ng} \mathrm{mL}^{-1}\right)$. All samples were tested three times in parallel using the ICP-MS analysis system. The concentration of purified gold clusters was determined by ICP-MS analysis system. The calculation formula is as follows:

$$
C=5000 \rho / M_{A u} N_{A u}
$$

$\mathrm{C}$ : molar concentration of $\mathrm{AuCs}(\mathrm{M})$

$\rho$ : mass concentration of $\mathrm{Au}$ ions (atoms) measured from ICP-MS analysis $\left(\mathrm{g} \mathrm{L}^{-1}\right)$

$\mathrm{M}_{\mathrm{Au}}$ : relative atomic mass of $\mathrm{Au}\left(\mathrm{g} \mathrm{mol}^{-1}\right)$

$\mathrm{N}_{\mathrm{Au}}$ : the number of $\mathrm{Au}$ atoms contained in each cluster

\section{Text S2. Expression of N-cadherin and Invasion Ability of PANC-1 and BxPC-3 Cells} Western Blot. PANC-1 and BxPC-3 cells were seeded into petri dishes and cultured in DMEM supplemented with L-glutamine $(4 \mathrm{mM})$, penicillin $\left(100\right.$ units $\left.\mathrm{mL}^{-1}\right)$, streptomycin $\left(100 \mu \mathrm{g} \mathrm{mL}^{-1}\right)$ and $10 \% \mathrm{FBS}$ at $37{ }^{\circ} \mathrm{C}$ in an atmosphere containing $5 \% \mathrm{CO}_{2}$. After $24 \mathrm{~h}, \mathrm{PANC}-1$ and BxPC-3 cells were washed with ice-cold PBS before lysed with $600 \mu \mathrm{L}$ of cell lysis buffer and a protease inhibitor cocktail tablet for $15 \mathrm{~min}$ at $4{ }^{\circ} \mathrm{C}$. The cell supernatant was then collected by centrifugation at $12000 \mathrm{rpm} \mathrm{min}-1$ for $10 \mathrm{~min}$ at $4{ }^{\circ} \mathrm{C}$. The protein concentration was measured by the BCA assay kit to ensure the consistency of the sample amount in gel electrophoresis. Then, the protein samples were mixed with $5 \times$ loading buffer, heated at $100{ }^{\circ} \mathrm{C}$ for $5 \mathrm{~min}$, and separated by $10 \%$ sodium dodecyl sulfate-polyacrylamide gel electrophoresis (SDS-PAGE). After SDS-PAGE, the protein was transferred to polyvinylidene difluoride (PVDF) membranes. The protein was then successively labeled with $\mathrm{N}$-cadherin specific antibody and goat anti-rabbit HRP-labeled secondary antibody. Finally, the protein bands were detected by Immobilon Western Chemiluminescent HRP Substrate. Chemiluminescence signal on PVDF membrane were collected 
by Tanon 5200 Multi Digital Image System. The band intensities were quantified by densitometry in ImageJ for triplicate.

Transwell Invasion Assay. First, $100 \mu \mathrm{L}$ of Matrigel (300 mg mL $\mathrm{mL}^{-1}$ in serum-free medium) was added into the insert membrane of transwell plates and then dried at $37{ }^{\circ} \mathrm{C}$ for $5 \mathrm{~h}$. After being treated with serum-free medium for $24 \mathrm{~h}$, the cells were digested with trypsin and suspended to a cell density of $5 \times 10^{5}$ cells $\mathrm{mL}^{-1}$ in serum-free medium. A volume of $200 \mu \mathrm{L}$ of the cells suspension were loaded to the upper chamber, while the lower chamber containing $10 \%$ FBS as a chemoattractant. After $24 \mathrm{~h}$ of culture, the cells were fixed in the upper chamber with paraformaldehyde. Then, the cells remaining in the upper chamber were removed by cotton swabs, and the membrane was stained by $0.1 \%$ crystal violet. Finally, the cells on the lower surface of the membrane were imaged under a microscope and counted in at least three random microscopic fields.

\section{Text S3. Quantification of Average N-cadherin Expression Level in a Single Cell by ICP-MS}

The formula for calculating the mole number and number of AuCs on a single cell can be followed by Equation (2) and Equation (3).

$$
\begin{gathered}
n=\rho V / M_{A u} N_{\text {cell }} N_{A u} \\
N=\rho V N_{A} / M_{A u} N_{\text {cell }} N_{A u}
\end{gathered}
$$

$\mathrm{n}$ : average mole number of AuCs per cell

$\mathrm{N}$ : average number of AuCs per cell

$\rho$ : mass concentration of $\mathrm{Au}$ ions (atoms) measured from ICP-MS analysis $\left(\mathrm{g} \mathrm{L}^{-1}\right)$

V: ultimate volume of the analyzed system (L)

$\mathrm{N}_{\mathrm{A}}$ : Avogadro's number

$\mathrm{M}_{\mathrm{Au}}$ : relative atomic mass of $\mathrm{Au}\left(\mathrm{g} \mathrm{mol}^{-1}\right)$

$\mathrm{N}_{\text {cell: }}$ the number of cells

$\mathrm{N}_{\mathrm{Au}}$ : the number of $\mathrm{Au}$ atoms contained in each cluster

On the basis of the recognition ratio of one $\mathrm{N}$-cadherin molecule for per cluster, the amount of AuCs is the expression amount of $\mathrm{N}$-cadherin on each cell. 
Text S4. Distribution Study of Tumor Cells with High Fixed Number on the Electrode Surface

To determine whether tumor cells are distributed in a single layer on the electrode surface with a large number, the DAPI-stained cells were observed using the Z-axis scanning mode of the CLSM system. In detail, PANC-1 cells and BxPC-3 cells in the culture dishes were scraped off and collected into a centrifuge tube. After the cells were immobilized and blocked, $1 \mathrm{~mL}$ of $10 \mu \mathrm{M}$ AuCs was added to the centrifuge tube before the tube was shaken gently at room temperature for

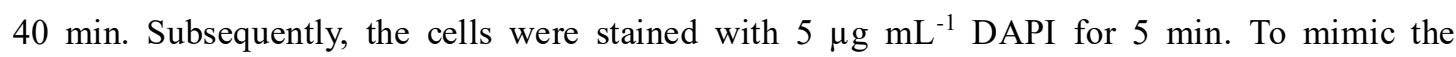
PDA/GCE surface, $20 \mu \mathrm{L}$ of $50 \mathrm{mM}$ pH 8.5 Tris buffer solution containing $2 \mathrm{mg} \mathrm{mL}^{-1}$ dopamine hydrochloride, $4 \mathrm{mM} \mathrm{CuSO}_{4}$, and $20 \mathrm{mM} \mathrm{H}_{2} \mathrm{O}_{2}$ were dropped onto the surface of transparent glass slides. After polymerization at room temperature for $30 \mathrm{~min}$, the slides were rinsed with ultrapure water and dried. To observe the distribution of cells, $2.0 \times 10^{4}$ PANC- 1 and BxPC-3 cells stained by DAPI were uniformly fixed onto the surface of PDA modified slides. It should be mentioned that, sample area dripping on the glass slide equals to that on the electrode surface. Finally, the cells were observed with a 1.4 numerical aperature non-oil immersion $20 \times$ objective, and individual image was taken along their Z-axis at $0.5 \mu \mathrm{m}$ intervals.

\section{Text S5. Counting the Number of Tumor Cells Trapped on the Electrode Surface}

In order to confirm the number of the tumor cells trapped on the electrode surface, after DPV measurements, we observed cells attachment on PDA/GCE by SEM. To be specific, the detachable glassy carbon electrode was immersed in $50 \mathrm{mM}$ pH 8.5 Tris buffer solution containing $2 \mathrm{mg} \mathrm{mL}^{-1}$ dopamine hydrochloride, $4 \mathrm{mM} \mathrm{CuSO}_{4}$, and $20 \mathrm{mM} \mathrm{H}_{2} \mathrm{O}_{2}$ at room temperature for 30 min to obtain PDA/GCE. Subsequently, the gradient number of cells $\left(0.50,0.90,1.2,1.5,2.0 \times 10^{4}\right)$ labeled by AuCs were evenly fixed onto the surface of the detachable glassy carbon electrodes, and DPV measurement was performed under the same conditions. After the detachable glassy carbon electrodes were dried in vacuum at room temperature, they were fixed on the sample stage with electric conductive adhesive for SEM measurement. The number of cells on the electrode surface is counted as follows. Three different fields of vision were randomly selected on each electrode, and the number of cells within the field of vision was averaged after counting. The number of tumor cells fixed on the electrode was estimated according to the ratio of the field of view area of the SEM image to the sample area dripping on the electrode surface. 


\section{Text S6. In situ Electrochemical Detection of N-Cadherin Expression on a Single Cell}

Taking 5000 PANC-1 cells as an example, the peak DPV current of modified electrode is $13.9 \mu \mathrm{A}$. The corresponding amount of substance of AuCs can be obtained from the electrochemical standard curve, which is recorded as $\mathrm{n}_{\mathrm{AuCs}}$. Then the average mole number and number of AuCs identified on each cell can be calculated by Equation (4) and Equation (5).

$$
\begin{gathered}
n=n_{\text {AuCS }} / N_{\text {cell }} \\
N=n_{A u C S} N_{A} / N_{\text {cell }}
\end{gathered}
$$

$\mathrm{n}_{\mathrm{AuCs}}$ : the amount of substance of AuCs recognized on the surface of the electrode

$\mathrm{N}_{\mathrm{A}}$ : Avogadro's number

$\mathrm{N}_{\text {cell: }}$ the number of cells

\section{Text S7. Quantifying the Expression Level of N-cadherin on CaSki Cells by ICP-MS and}

\section{Electrochemical Method}

As illustrated in Figure S12, the expression level of N-cadherin on CaSki cells was quantified by two methods under the optimal labeling conditions. The amount of $\mathrm{N}$-cadherin on a single CaSki cell is $131.7 \pm 12.0$ amol determined by ICP-MS analysis (Figure S12A). For the electrochemical analysis of CaSki cells, when the cells number varies from $1.5 \times 10^{4}$ to $2.5 \times 10^{4}$, the corresponding DPV peak current changes from $9.97 \mu \mathrm{A}$ to $12.0 \mu \mathrm{A}$. Applying the peak current value of DPV to the standard curve, the expression of N-cadherin on the CaSki cell surface is calculated to be $136.0 \pm 7.0$ amol (Figure S12B). In other words, the expression number of $\mathrm{N}$-cadherin in each CaSki cell is about $(7.93 \pm 0.72) \times 10^{7}$ and $(8.20 \pm 0.42) \times 10^{7}$ determined by ICP-MS and electrochemical analysis, respectively. 


\section{Supplementary Figures}

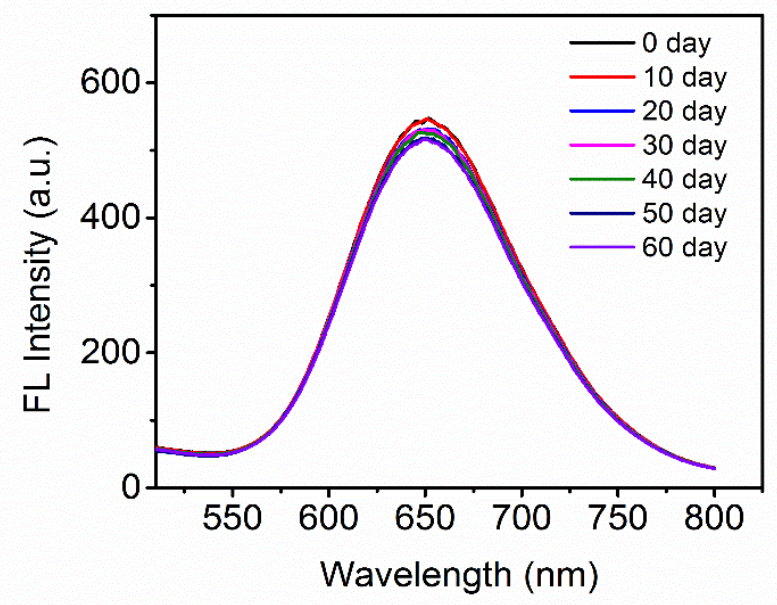

Figure S1. Fluorescence intensity of peptide modified AuCs within 60 days.
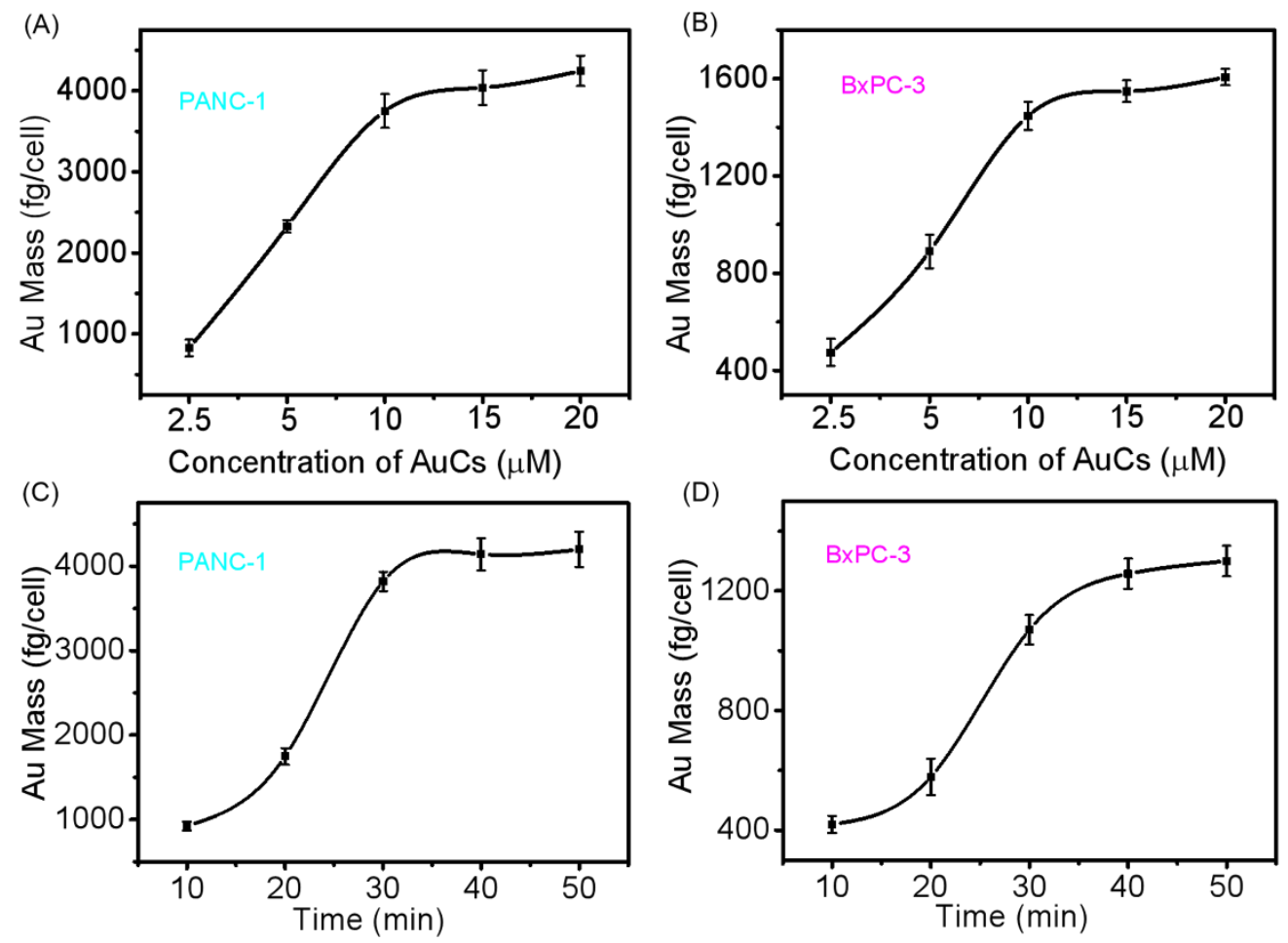

Figure S2. Optimization of labeling condition of peptide modified AuCs on cells by (A, B) changing the AuCs concentration $(2.5,5.0,10,15,20 \mu \mathrm{M})$ with fixed incubation time for $40 \mathrm{~min}$; and $(\mathrm{C}, \mathrm{D})$ varying incubation time $(10,20,30,40,50 \mathrm{~min})$ with fixed $10 \mu \mathrm{M}$ AuCs. 


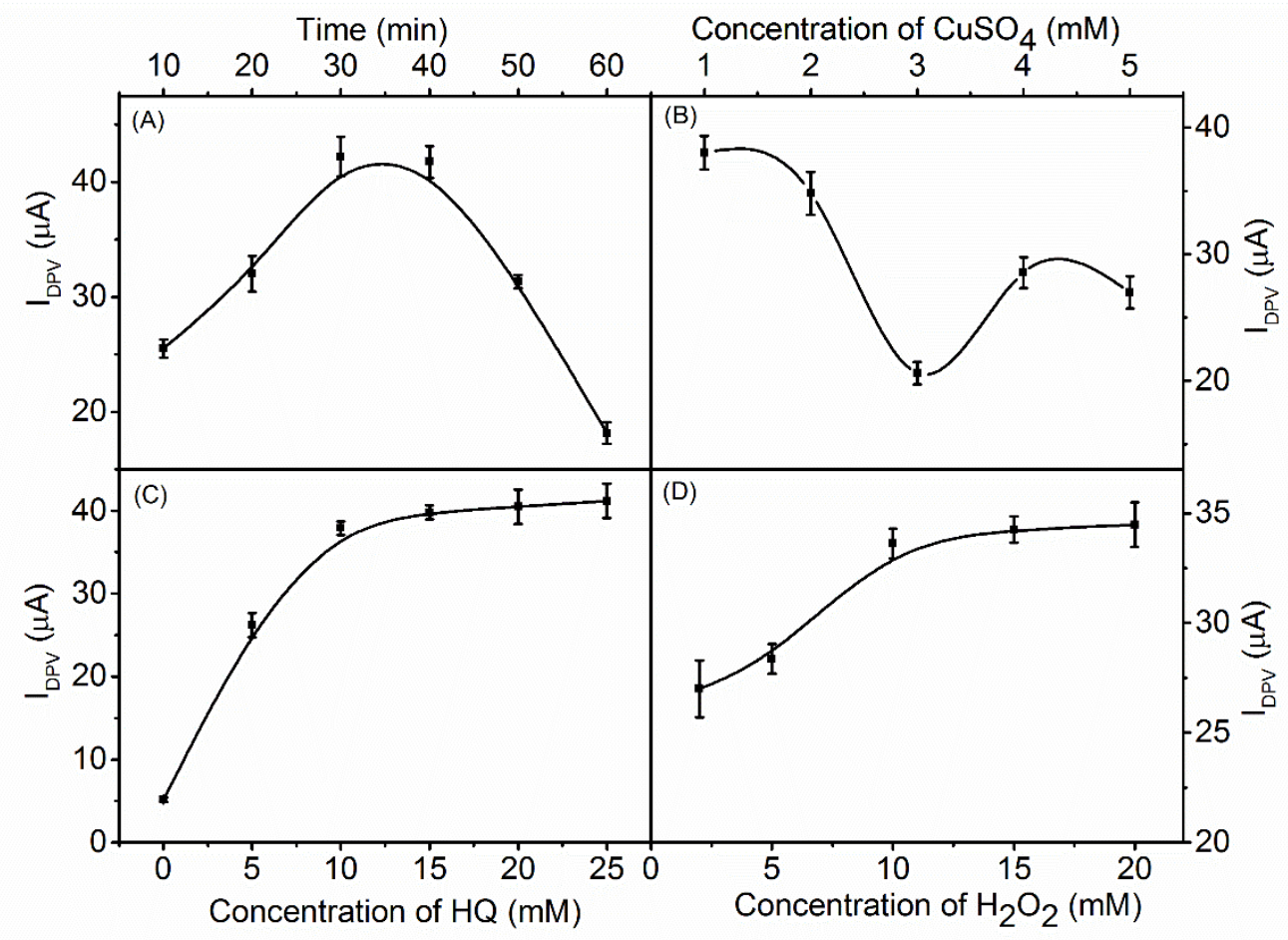

Figure S3. (A) Changes of DPV peak current with PDA polymerization time. (B) Changes of DPV peak current with $\mathrm{CuSO}_{4}$ concentration. (C) Effect of HQ concentration on DPV peak current. (D) Influence of $\mathrm{H}_{2} \mathrm{O}_{2}$ concentration on DPV peak current.

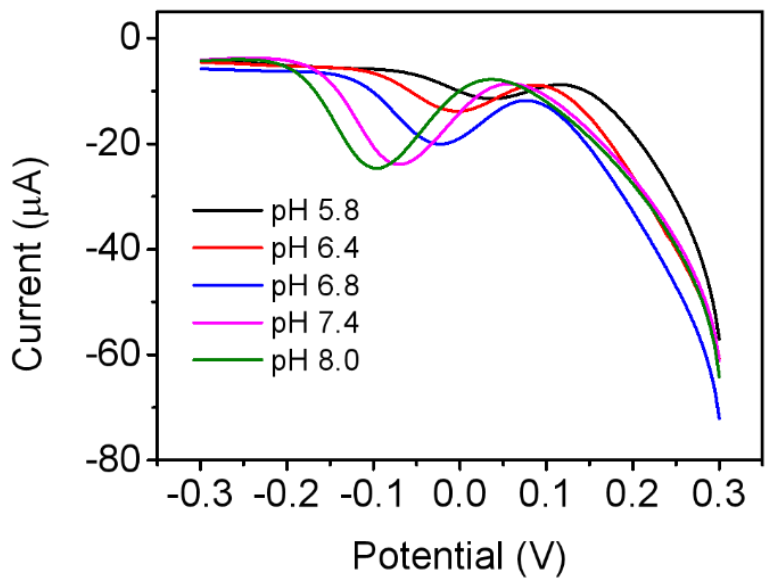

Figure S4. pH-dependent DPV peak responses of AuCs/PDA/GCE in $0.1 \mathrm{M}$ PBS containing 10 $\mathrm{mM} \mathrm{HQ}$ and $10 \mathrm{mM} \mathrm{H}_{2} \mathrm{O}_{2}$. 


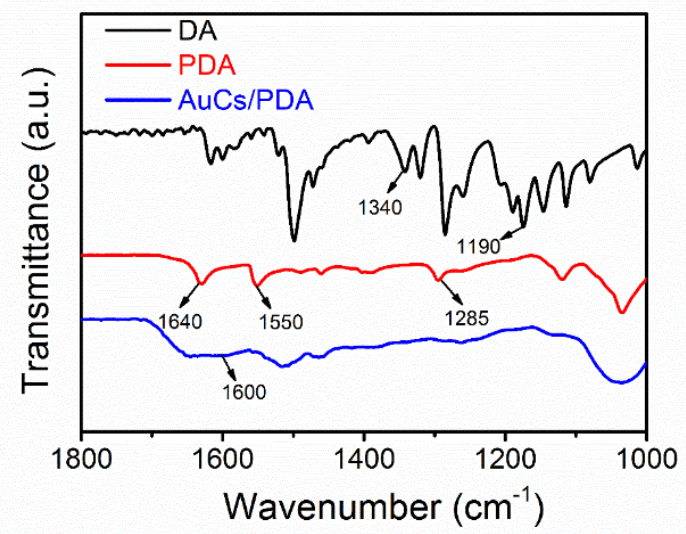

Figure S5. FTIR Spectra of DA, PDA and AuCs/PDA.
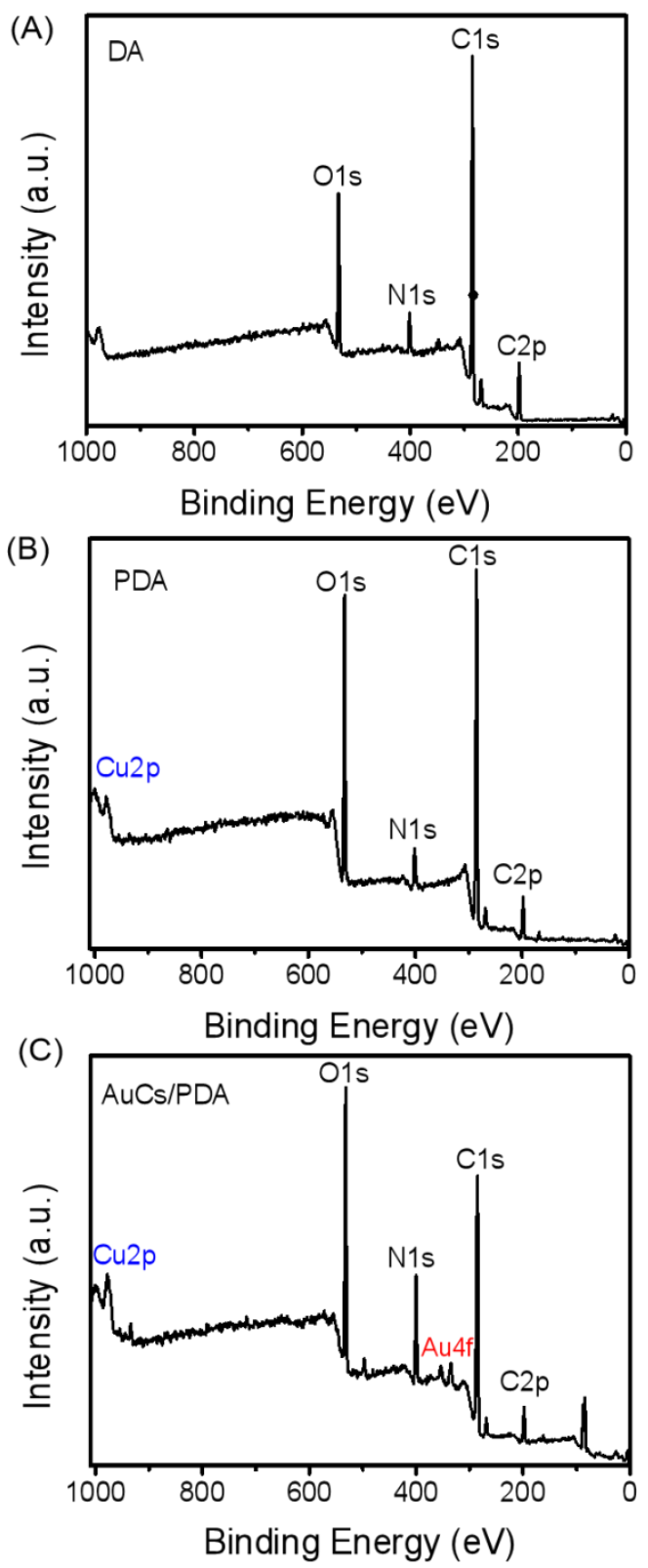

Figure S6. XPS spectra of (A) DA, (B) PDA and (C) AuCs/PDA. 

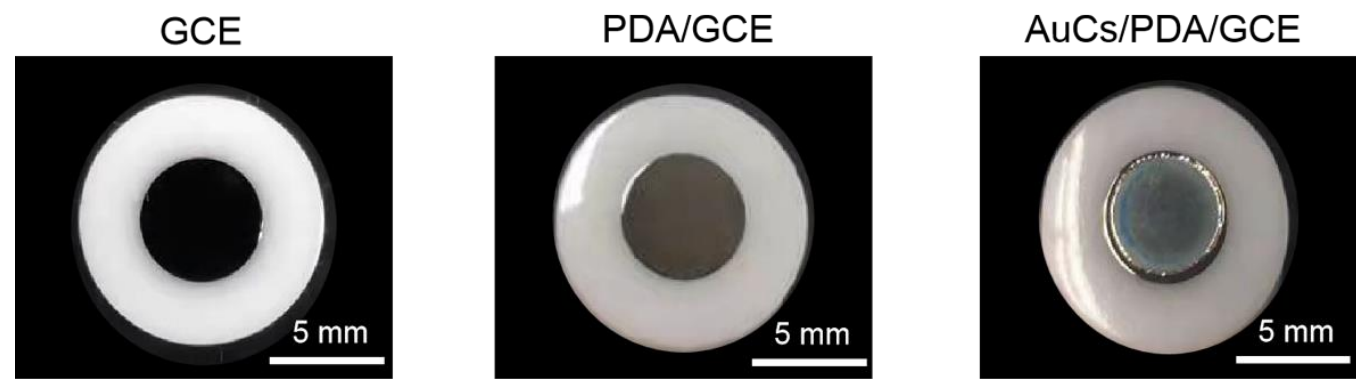

Figure S7. Images of the surface morphology of the electrode during electrode modification.
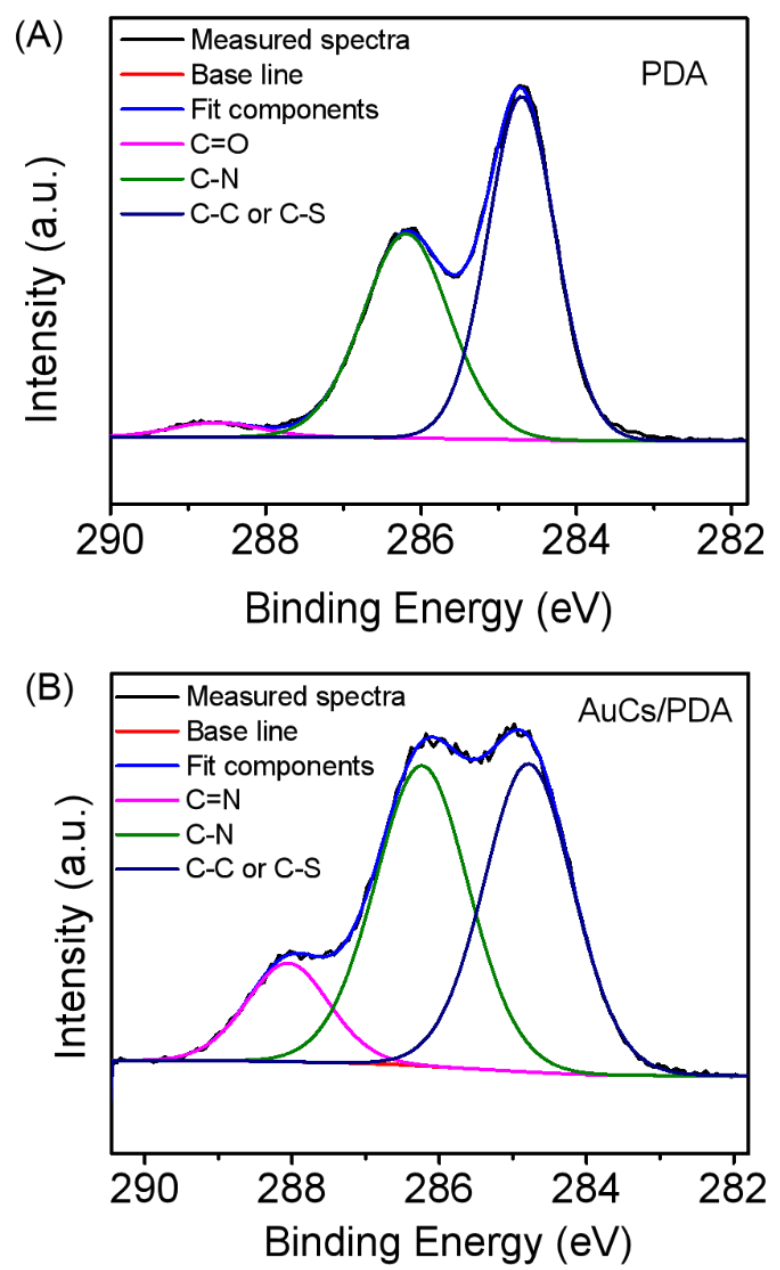

Figure S8. XPS analysis of the C 1s patterns of (A) PDA and (B) AuCs/PDA. 

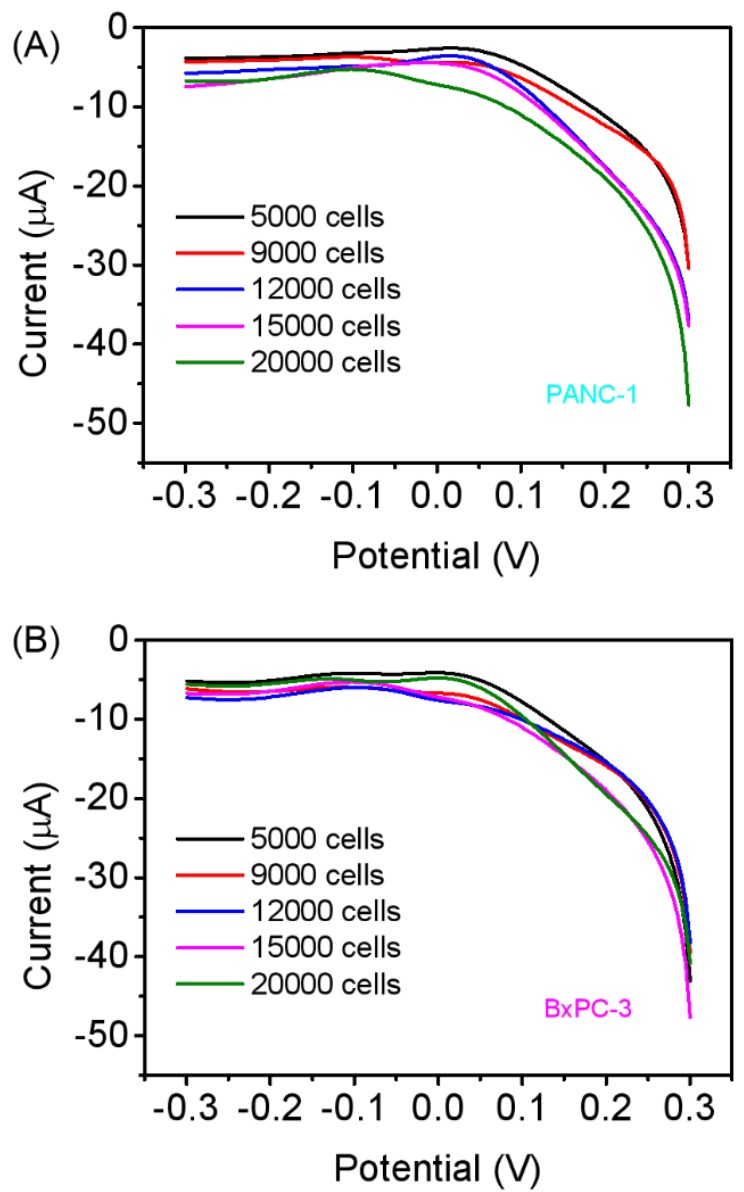

Figure S9. DPV responses of cells/PDA/GCE in $0.1 \mathrm{M}$ PBS containing $10 \mathrm{mM}$ HQ and $10 \mathrm{mM}$ $\mathrm{H}_{2} \mathrm{O}_{2}$. The numbers of fixed PANC-1 and BxPC-3 cells vary from 5000 to 20000 . 


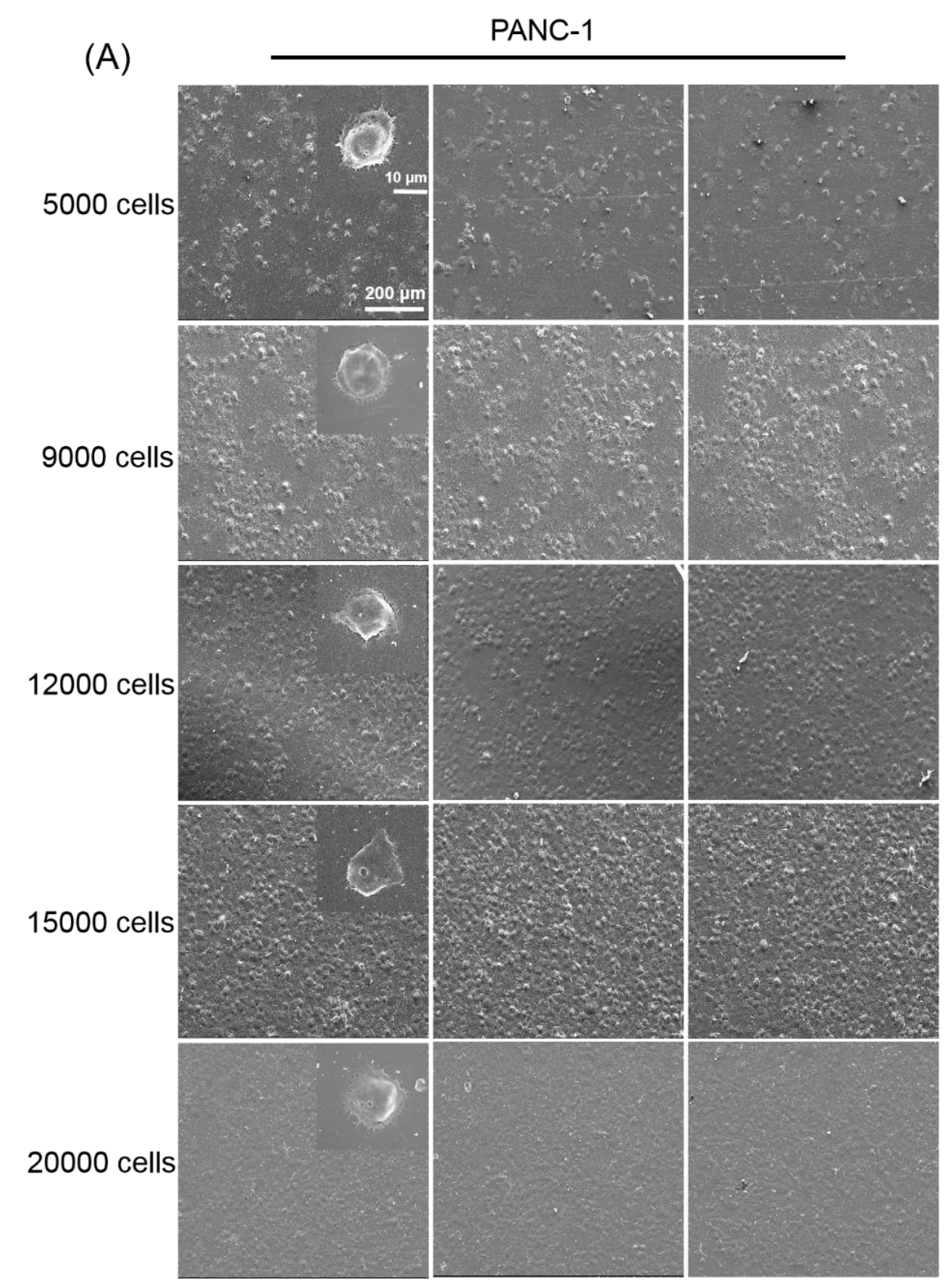




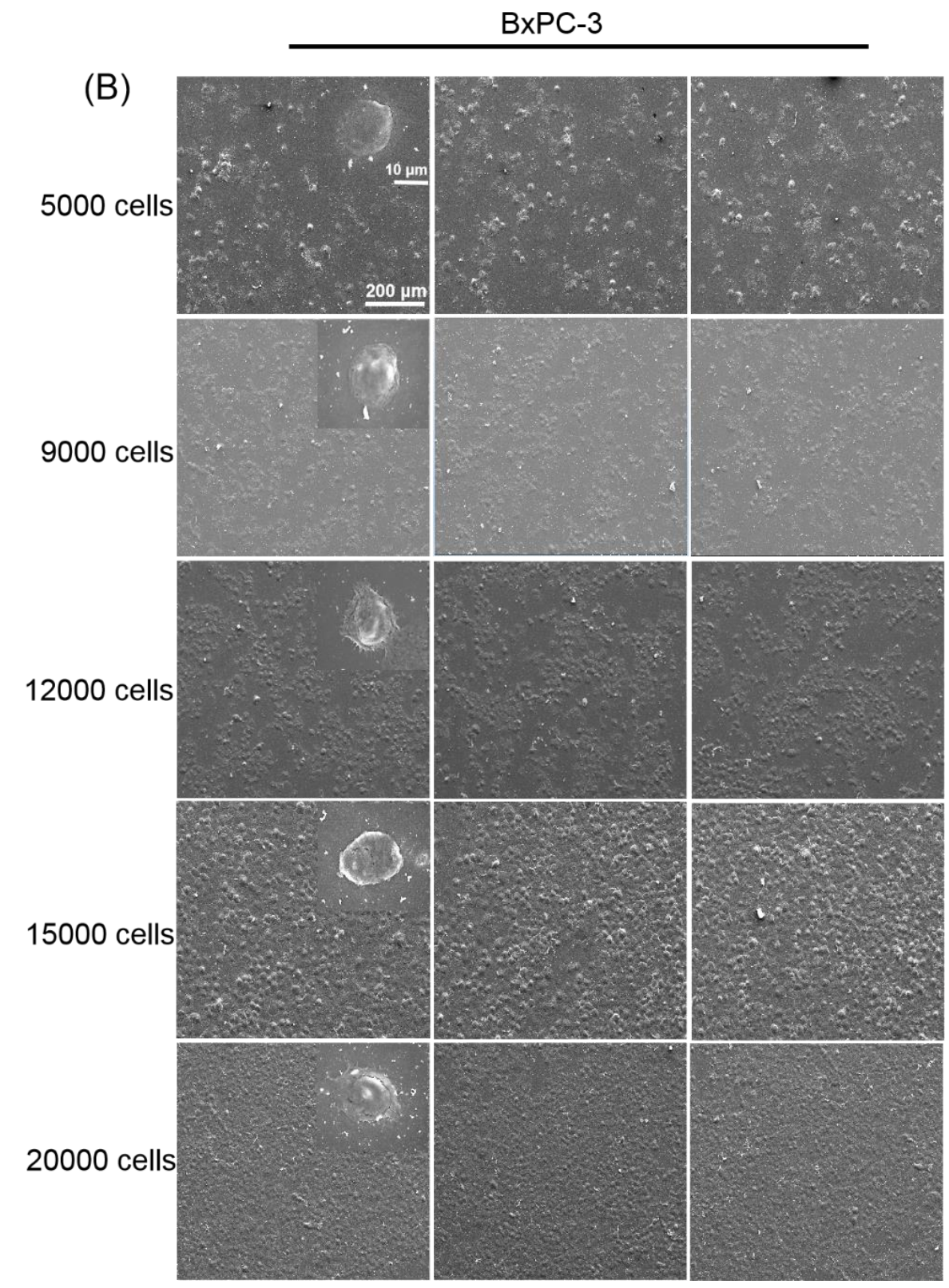

Figure S10. Images of PANC-1 (A) and BxPC-3 (B) cells fixed on the detachable glassy carbon electrode plates after DPV testing observed by SEM. Three different fields of vision were randomly selected on each electrode for tumor cells counting. The enlarged image presents a representative single cell. 

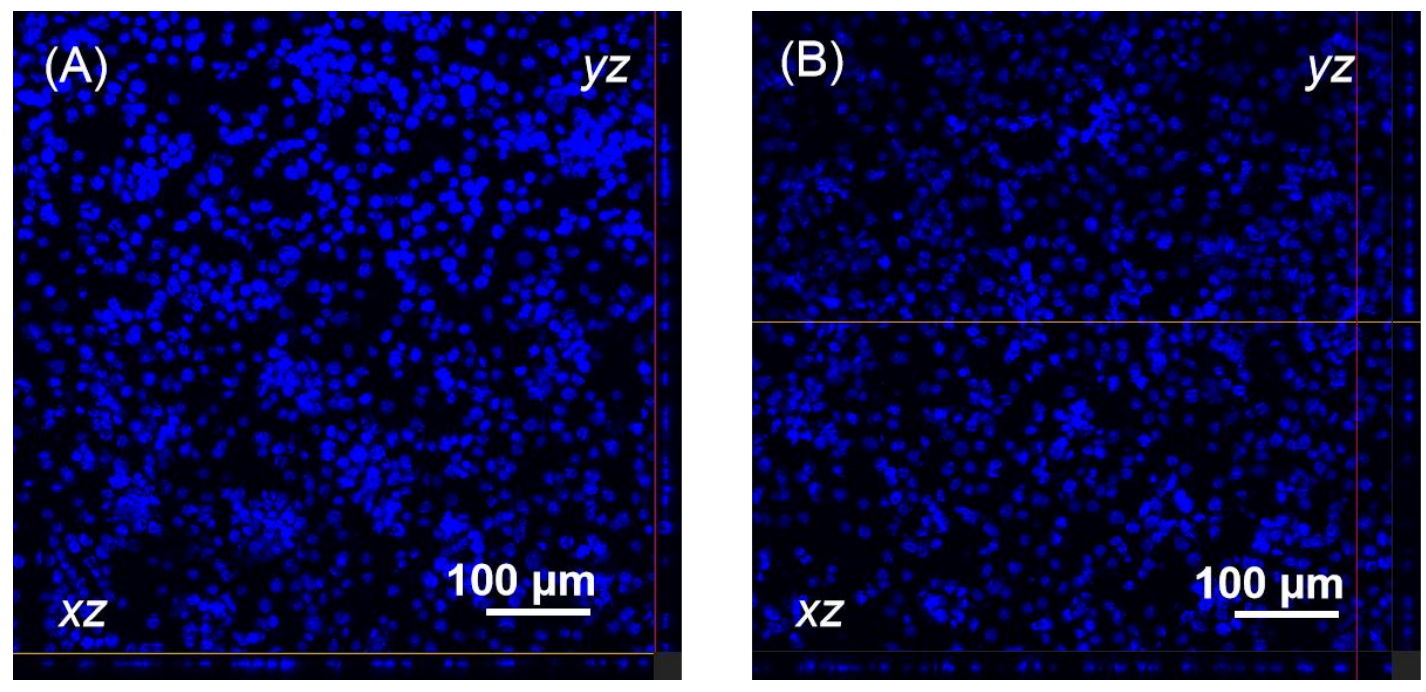

Figure S11. CLSM images of $2.0 \times 10^{4}$ PANC-1 (A) and BxPC-3 (B) cells modified glass slides surface. The cell nuclei were stained with DAPI (blue). The central image shows the $x-y$ top view at a given $\mathrm{z}$ and two other images are on the respective $\mathrm{x}-\mathrm{z}$ and $\mathrm{y}-\mathrm{z}$ side views. The lines represent the position where the stack is cut to form the $\mathrm{xz}$ and $\mathrm{yz}$ sections. 
(A)

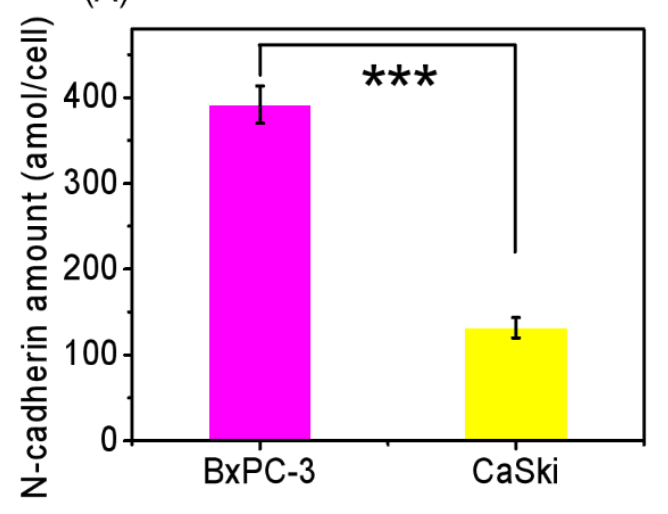

(B)

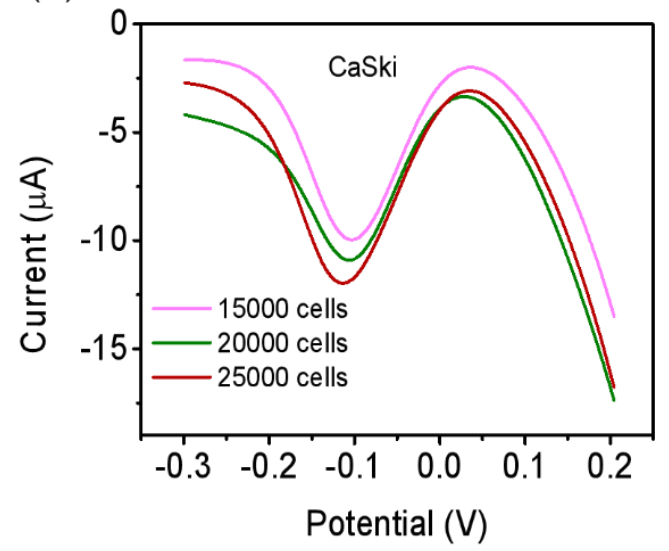

Figure S12. (A) Quantitative analysis of $\mathrm{N}$-cadherin in a single BxPC-3 and CaSki cell by ICP-MS. ${ }^{* *} p<0.001$. (B) DPV responses to CaSki cell numbers. 